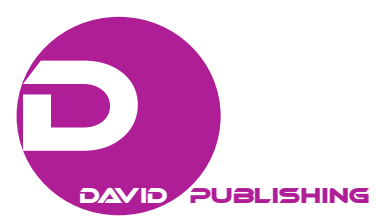

\title{
Changes of Wage Structures in Chinese Public and Private Sectors: 1995-2007*
}

\author{
Xinxin Ma \\ Hitostubashi University, Tokyo, Japan
}

\begin{abstract}
Using CHIP (Chinese Household Income Project Survey) data and the sample selection bias corrected wage function model, this paper estimated changes in wage structure in China by ownership types (SOEs, COEs, FEs, and PEs) in 1995 and 2007. The major conclusions are as follows. First, effects of education on wage levels in SOEs and FEs become greater, while education effects decrease in SOEs and PEs under economic transition periods; firm-specific human capital becomes more important in the wage determination mechanism along with market-oriented reforms in SOEs, PEs, and FEs; age effect decreases in SOEs and COEs, but it becomes greater in PEs and FEs. Second, there exist wage structure differences between sectors by wage distributions. For example, in 2007, in SOEs, education return rates are higher for the low-wage and middle-wage groups, and the effect is the highest at the 40th percentile. However in COEs and FEs, education return rates are higher for the high-wage groups, and the effect is the highest at the 70th percentile in COEs and at the 70th percentile in FEs. Tenure effects are greater in the middle-wage groups (40th-80th) in SOEs, COEs, and FEs, and age effects are greater in the low-wage groups (5th-30th) in SOEs, FEs, and PEs.
\end{abstract}

Keywords: public and private sectors, wage structure, human capital, Chinese economic transition

\section{Introduction}

The wage determination mechanism is relation to the wage level and labor income distribution in GDP, so it is an important issue for government and firms. Although neoclassical economic theory emphasizes that wages in perfectly competitive markets are decided by labor demand and supply and by the principles of utility maximization for individuals and profit maximization for firms, otherwise according to internal labor market theory in institutional economics, wage decisions are also related to firms' internal practices (e.g., payment and employment systems in firms) (Piore, 1970) ${ }^{1}$. In this study, an empirical study is conducted to reveal the changes of wage determinants mechanism through an investigation on the changes of wage structures

\footnotetext{
* Project Support: This research was supported by grant-in-aid for scientific research (numbers 25380297 and 16K03611) of JSPS (Japan Society for the Promotion Science). I would like to thank professor Katsuji Nakagane (Tokyo University), professor Go Yano (Kyoto University), associate professor Kazufumi Yugami (Kobe University) for their helpful comments in 2014 Chinese Economic Workshop in Kyoto University, 2014 Chinese Economic Workshop in Kobe University, 2015 International Conference "Economy Transition and Income Inequality in China” in Kyoto University.

Xinxin Ma, Ph.D., (economics), associate professor, Institute of Economic Research, Hitotsubashi University, Tokyo, Japan.

Correspondence concerning this paper should be addressed to Xinxin Ma, Institute of Economic Research, Hitotsubashi University, 2-1 Naka, Kunitachi-shi, Tokyo, 186-8603, Japan.

${ }^{1}$ In addition, the government establishes wage policies, for example, the Minimum Wage policy, and trade unions influence wages through collective bargaining, for more information of the Minimum Wage policy in China, please refer to Ma (2014); for the empirical studies on the Minimum Wage effects on the male and female wage levels in China, please see Li and Ma (2015).
} 
under economic transition periods in China.

Wage determining mechanisms in China transformed between its planned economy period (from 1949 to 1977) and economic transition period (post to 1978). In planned economy period, to promote priority development of heavy manufacturing industry during the planned economy period, China's government enforced low-wage labor policies to increase employment and established a unified-management wage system in the public sector, the Chinese government enacted its united management wage policy to set wage levels and control wage growth ranges (Meng \& Kidd, 1997; Bowles \& White, 1998; Yamamoto, 2000; Marugawa, 2002; Ma, 2006; 2014). These wage policies and systems did not incentivize work efforts and both labor productivity and enterprise effectiveness were low. To solve these problems, China's government deregulated wage policies after the 1980s, for example, the State Council promulgated the enforcement of bonus and piece wage in 1978 and established policies concerning the upper limits of and tax rates applicable to bonuses in 1983 and 1984. During the 1980s, mechanisms for deciding workers' wages became better aligned with enterprise's efficiency and profit, and individual human capital based on education was more highly rewarded (Meng \& Kidd, 1997). In the 2000s, along with the regulation enforced by Chinese government for the transition to modern management systems in SOEs, the government gives SOEs more autonomy in determining labor employment and individual worker wage level. Even as China shifted to a marketization economy, Lin, Cai, and Li (1996) and Nakagane (1999) pointed out that it was "an incompleteness reform”. For example, it is debated that even though most small state-owned enterprises (SOEs) and collective-owned enterprises (COEs) were privatized, but the governance of large SOEs scarcely changed, the seniority wage system still affects the wage levels largely in the SOEs. Otherwise, with the economic opening (e.g., deregulations of FDI, import and export), foreign investment enterprises (FEs) and private enterprises (PEs) are dramatically developing after the 1980s. The market wage determinants mechanism affects the wage levels in these private sectors greatly. Did ownership reforms and wage policy changes influence wage structure of SOEs?

This paper examines changes in wage structures among SOEs, COEs, PEs, and FEs sectors during economic transition. Previous empirical studies have investigated this issue. Dong and Bowles (2002); Xing (2006); Demurger, Fournier, Li, and Wei (2007); Yin and Gan (2009); and Ma (2009; 2014) revealed that wage structures were different between SOEs and non-SOEs, and indicated that human capital exerted greater influence on wages among non-SOEs than SOEs. Chen, Demurger, and Fournier (2005); Zhang and Xue (2008); Ye, Li, and Luo (2011); Demurger, Li, and Yang (2012); and Zhang (2012), Ma (2014; 2015) decomposed the determinants of wage differentials between public and private sectors (or between SOEs and non-SOEs) and showed that individual human capital factors in relation to labor productivity are main factors to explain the wage differentials between two sectors.

However, these studies use annual and monthly wages as dependent variables and ignore working hours. If working hours are longer in the private sector, using annual and monthly wages rather than hourly wages (or wage rates) might underestimate differentials. In addition, empirical study on wage structures and wage differentials from the early 1990s to the late 2000s is scarce and information is lacking about changes in wage structures over that extended period. Although Ma (2015) utilized wage rate and estimated the wage structures in public and private sectors, but she did not distinguish the ownership types into SOEs, COEs, PEs, and FEs, so the details on the differences of wage structures by the kinds of ownership types are not clear. It is thought that because the wage and employment systems are different by ownership types, so the wage structures perhaps are different among SOEs, COEs, PEs, and FEs. 
In this study, using two waves (1995 and 2007) of Chinese Household Income Project Survey data (CHIPs) in urban China, two questions are investigated. They are: (1) Are there wage structure differences among SOEs, COEs, FEs, and PEs? (2) Are there wage structures different by wage distributions? Using two period survey data, changes in wage structure can be estimated among sectors.

The paper is structured as follows: part 2 introduces the framework of the empirical analysis, including models and datasets; part 3 presents estimation results; and part 4 gives summary of conclusions.

\section{Methodology}

\section{Models}

To measure wage structure differentials, first, wage functions based on variable means are utilized. Heckman (1979) and Maddala (1983) pointed out that Ordainary Least Squares (OLS) model lefts a sample selection bias problem, so the selectivity-bias corrected wage function model is used to address it. Because there exist many kinds of sector selections (e.g., the choices from the employment status of PGs, SOEs, COEs, PEs, and FEs), Maddla's model based on a multinomial logit model analysis is utilized in this study. Maddala's model is expressed as equations (1)-(3).

In equations (1)-(3), $i$ denotes workers; $s$ is an index indicating the sector (SOEs, COEs, PEs, FEs, and others); and $\ln W$ indicates the dependent variable (as a logarithm of the wage rate). $X$ are factors affecting wages and $\beta$ are the estimated coefficients of $X$. Further, $\alpha$ is a constant and $\mu$ is the error term.

$$
\begin{gathered}
\ln W_{s i}=a_{s}+\beta_{s} X_{s i}+u_{s i} \quad(s=1,2, \cdots \cdots, M) 、(i=1.2 \cdots, N) \\
P\left(\varepsilon_{s}<\gamma Z_{s}\right)=P(I=s)=\frac{\exp \left(\gamma Z_{s}\right)}{\exp \left(\gamma_{s} Z_{s}\right)+\sum_{\substack{j=1,2 \cdots M \\
j \neq s}} \exp \left(\gamma_{j} Z_{j}\right)} \\
(s=1,2, \cdots \cdots, M) 、(i=1.2 \cdots, N) \\
I=s \quad \text { if } \quad \gamma Z_{s}-\gamma Z_{j}>u_{j}-u_{s} \quad j=1.2 . \cdots, M \quad(j \neq s)
\end{gathered}
$$

Equation (2) expresses the wage function estimated by OLS model. Equation (2) expresses the probability of the one work in the sector which he (she) entries to. ${ }^{2}$ The choice of sector $s$ is expressed as $I^{*}=s$ employment and the choice of the other sector employment is expressed as $I^{*}=0 . Z$ indicates the factors affected the entry possibility to each sector. $Z$ composes an identification variable (resembling an instrument variable: IV). The married dummy is used as an identification variable in this paper. ${ }^{3}$ Using the estimated results of the distribution function and the density function of the sector selection probability, correct items $\left(\lambda=\phi\left(\gamma Z_{s}\right) / \Phi\left(\gamma Z_{s}\right)\right.$ are calculated. The selectivity-bias corrected wage functions expressed by equation (3) can be estimated using correct items.

\footnotetext{
${ }^{2}$ Although this paper focuses on wage structures between sectors, it believes that sample selection bias also appears in the worker's choice of workers and non-workers. Therefore, the unemployed is sampled in employment status choice functions, so multi-probabilities are used when imputed wages are calculated.

${ }^{3}$ The reasons of the married status variable are used as identification variables in this paper as the following. According to statistical discrimination theory, in the private sector, if employers consider the average work willingness of single women higher than that of married women, it is thought that the possibility for the married women to be employed is lower than single women. Because gender equality in employment was promoted in the SOEs during the planned economy period, it can be thought that the influence of marriage status on employment in SOEs is smaller.
} 


$$
\ln W_{s}=a_{s}+\beta_{s} X_{s}+\beta_{\lambda} \lambda_{s}+v_{s}
$$

To reveal the wage structures by wage distributions, quantile regression models (Koenker \& Bassett, 1978) derived from the wage distribution are utilized. These models are expressed as equations (4), $\theta$ is an index indicating the wage percentile:

$$
\begin{gathered}
\min _{X(\theta)}\left[\sum_{h: \ln W_{i} \geq \beta(\theta) X_{i}} \theta\left|\ln W_{i}-\beta(\theta) X_{i}\right|+\sum_{\left.h: \ln W_{i}<\beta \theta\right) X_{i}}(1-\theta)\left|\ln W_{i}-\beta(\theta) X_{i}\right|\right] \\
\rho_{\theta} \in(0,1)
\end{gathered}
$$

\section{Data}

This study employs two waves of survey data for urban registers: CHIP 1995 and CHIP 2007. These surveys were conducted by the Institute of Economic Research of Chinese Academy of Social Sciences (CASS), Beijing Normal University, and the National Bureau of Statistics (NBS) in 1996 and 2008. CHIP 1995 covers 11 provinces and CHIP 2007 covers nine provinces. CHIP 1995 encompasses 27,694 individuals and 5,003 households and CHIP 2007 encompasses 19,748 individuals and 6,931 households. Samples in six provinces (Jiangsu, Anhui, Henan, Hubei, Guangdong, and Sichuan) that are surveyed in both 1995 and 2007 are used. Based on CHIP (1995 and 2007) questionnaires, the samples can be divided into four subsamples: (1) SOEs, which contain government organizations, and units related to government organizations (Shiye danwei), and state-owned enterprises ${ }^{4}$; (2) COEs; (3) PEs; (4) FEs; (5) others.

The logarithm of the wage rate is the dependent variable. Monthly and annual wages include base salary, bonuses, and allowance; financial assets and public transfer payments are excluded. Monthly working hours are calculated using daily working hours and monthly working days. Wage rate is calculated based on total wage and working hours.

Independent variable settings are as follows. In wage functions, ownership dummy variables are divided into five categories: SOEs, COEs, PEs, FEs, and others. According to neoclassical economic theory, human

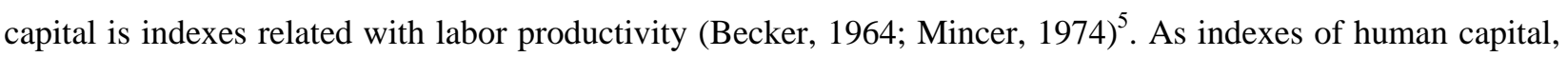
schooling years, tenure years, age, an occupational dummy (blue-collar worker job dummy), and an industry dummy (manufacturing industry dummy) are used in the study. It is believed that the effect of work experience (tenure) on wages includes an age effect and the firm-specific human capital effect (Ono, 1989; Ma, 2007; 2009). These two effects are considered in the analysis. Estimated age effect here shows the effect of seniority wage system performed by firms. It is thought along with the marketization economic transition progress, the effects of schooling years ("general human capital”) and tenure years ("firm special human capital”) should become greater, otherwise the age effects ( results from the seniority wage system) should become smaller.

\footnotetext{
${ }^{4}$ Because based on the Questionnaire items on ownerships in CHIP 1995, the government organizations and SOEs have not been distinguished, the samples compose of the government organizations, units related to government organizations (Shiye danwei) and SOEs are utilized as SOEs group. The wage structures of the government organizations group, units related to government organizations and SOEs group are estimated based on CHIP 2007. Because the results did not change greatly, so the sub-sample bias based on the definition of SOEs can be neglected.

5 Based on the human capital theory (Becker, 196; Mincer, 1974), the human capitals are divided into two types, they are-general human capital which can be utilized among all of firms, and firm special human capital which only can be utilized in special firm (e.g., the firm which the one is working for) and it is lost if he turns over.
} 
Employment status is divided into regular employees (long-term employment), non-regular employees (workers employed under a contact lasting less than one year and non-contract workers). Dummy variables for male, Han race are used as individual attributes, the married are used as an identification variable in sector selection functions. In addition, it is likely that labor market situations, such as labor supply and demand, and the labor policy implementation, such as the compliance of the Minimum Wage Policy are different among provinces (Li \& Ma, 2015; Ye, Li, \& Luo, 2011). Six province dummies (Jiangsu, Anhui, Henan, Hubei, Guangdong, and Sichuan) are used to control for these regional disparity.

Analysis objects are limited to employees aged from 16 to 59 and the self-employed and family workers are excluded. Sample sizes are 5,891 for CHIP (1995)—4,674 in SOEs, 1,089 in COEs, 24 in PEs, 104 in FEs, and 4,621 for CHIP (2007)—2,639 in SOEs, 267 in COEs, 1,573 in PEs, and 142 in FEs .

Figure 1 shows the kernel density estimations of the logarithm of the wage rate distribution in 1995 and 2007 by sectors. The wage distributions in 1995 and 2007 resemble normal distribution and the arithmetic mean values of the logarithm for the wage rate in SOEs and FEs are higher than those in COEs and PEs. In addition, the variances increase from 1995 to 2007 in all of these sectors, which evidences that the wage differentials within sectors rose during the economic transition period.
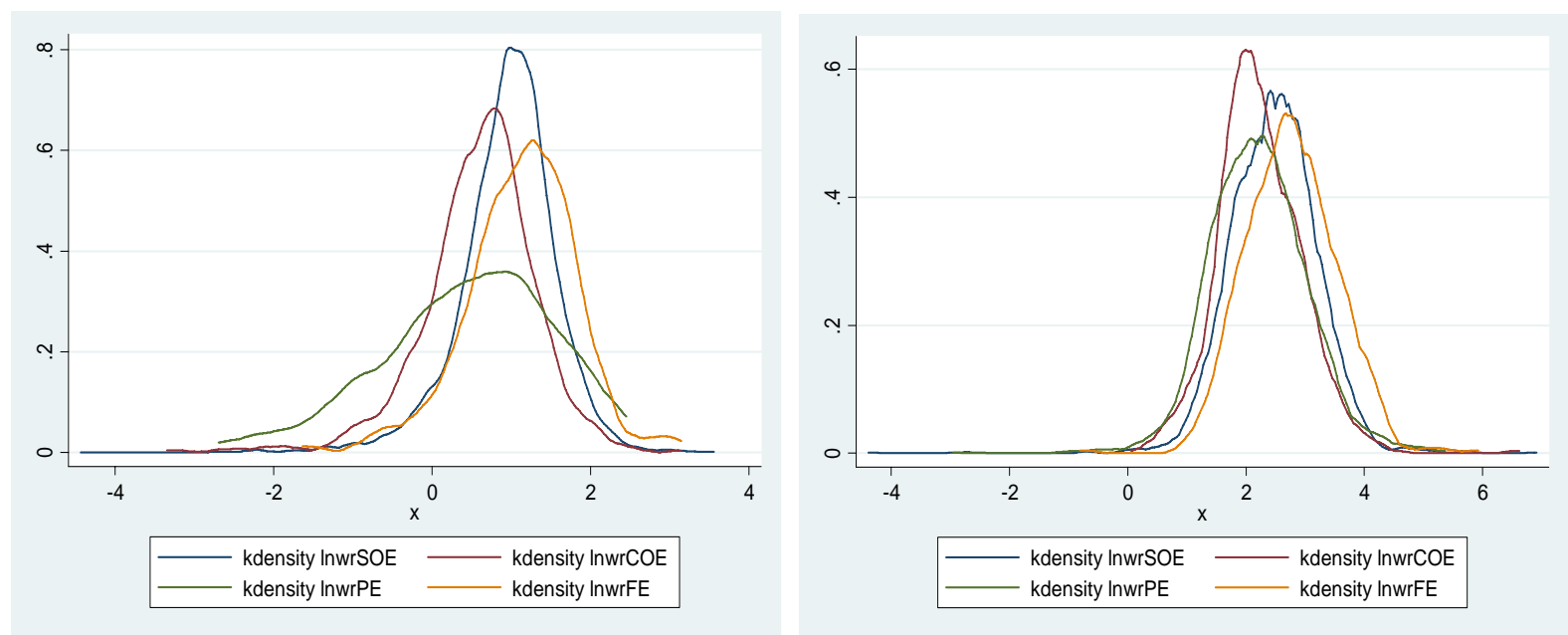

Figure 1. The Kernel density estimations of the logarithm of the wage rate distribution by sectors. Source: Calculated based on CHIP 1995 and CHIP 2007.

\section{Econometric Analysis Results}

\section{What Determinant the Entry to Public and Private Sectors?}

The estimated results of possibility functions for the ownership types are reported in Table 1 (1995), Table 2 (2007). The reference group is the non-worker group in these estimations. Following are the main conclusions:

First, effects of education in SOEs decreased from 12.8\% in 1995 to $8.7 \%$ in 2007, while rates of return on education in COEs rose from $-0.095 \%$ in 1995 to $0.47 \%$ in 2007 . In FEs, although the coefficients of educations are statistically insignificant in 1995, it affects the choice of entry to FEs statistically and the coefficient is the highest among sectors in 2007. In addition, the effects of education in PEs are smaller in both 1995 and 2007.

Along with the economic transition progress, the effects of general human capital on the probabilities of entry to different ownerships firms are becoming greater in the private sectors, and are also an important factor 
influencing the probability to entry to SOEs until recent period. The probabilities to entry to SOEs and FEs are higher for the group with the high education levels than for the group with the low education levels. Thus, the proportions of low-education workers or low-skill worker are higher in COEs and PEs, and the differentials of distributions of labor empowerment should affect the wage differentials between sectors, as it is proofed by some previous empirical studies in Zhang and Xue (2008); Ye, Li, and Luo (2011); Demurger, Li, and Yang (2012); and Zhang (2012); Ma (2015).

Second, compared with 30-39 aged group, the probabilities of entry to each sector are lower in the groups aged 40 and over, both in 1995 and 2007. In each sector, the probability to become a worker is the highest for 30-39 aged group.

Otherwise, although there do not exist statistical differences between youth group (16-19 aged group, 20-29 aged group) and 30-39 aged group in each sector in 1995, compared with 30-39 aged group, the probability of entry to SOEs, COEs, PEs, and FEs are all lower in 2007. The reasons for it can be considered as the follows. First, it is a result of the increase of college and university attendance rates. The government enforces the expansion of colleges and universities from the 1990s. As a result, the possibility to become a worker became lower along with more youth entry to college or university. Second, the problem that high education labors are over supplied is existing from the 1990s results from the expansion of colleges and universities attendance rates, youth unemployment is becoming a severe problem now. For example, the employment rate of college and university is just 50\%-70\% in China recently.

Third, coefficients of male dummy are statistically significant in the all sectors, both in 1995 and 2007. It shows that holding the other factors (such as human capitals) constant, compared with male, the female labor participations are lower relatively under economic transition period. It can be explained by two reasons. The one is similar with that in the developed countries - the female labor participations decrease along with the household income rise, which means the wife in rich household is more likely to become a homeworker and exit from the labor market voluntarily. The other one is pointed out by distinguished unemployment hypothesis and discrimination hypothesis - there exist gender discriminations in employment and wage, as a result, the possibility to entry to labor market is lower for female group.

Fourth, in 1995, the married positively affect the possibility to entry to SOEs and COEs, while they are statistically insignificant in PEs and FEs. Otherwise, in 2007, the positive effects of the married exist in all the sectors.

Fifth, there are regional disparities of possibility to entry to sectors, and these disparities changed from 1995 to 2007.

Table 1

Estimated Results of Probability Functions for the Firm Ownership Types (1995)

\begin{tabular}{|c|c|c|c|c|c|c|c|c|c|c|c|c|}
\hline \multirow{2}{*}{1995} & \multicolumn{3}{|c|}{ SOEs } & \multicolumn{3}{|c|}{ COEs } & \multicolumn{3}{|c|}{ PEs } & \multicolumn{3}{|c|}{ FEs } \\
\hline & coeff. & & t val. & coeff. & & t val. & coeff. & & t val. & coeff. & & t val. \\
\hline Schooling years & 0.128 & $* * *$ & 3.92 & -0.095 & $* * *$ & -2.77 & -0.023 & & -0.29 & -0.015 & & -0.29 \\
\hline \multicolumn{13}{|l|}{ Age (age 30-39) } \\
\hline Age 16-19 & -1.229 & $*$ & -1.63 & -0.695 & & -0.88 & -18.245 & & 0.00 & -0.361 & & -0.38 \\
\hline Age 20-29 & 0.190 & & 0.41 & 0.112 & & 0.23 & 0.538 & & 0.67 & 0.889 & & 1.55 \\
\hline Age $40-49$ & -0.711 & $* *$ & -2.44 & -0.836 & $* * *$ & -2.81 & -1.524 & $* *$ & -2.51 & -1.225 & $* * *$ & -2.91 \\
\hline Age 50-59 & -2.433 & $* * *$ & -8.20 & -2.816 & $* * *$ & -8.89 & -17.477 & & -0.02 & -3.042 & $* * *$ & -5.27 \\
\hline
\end{tabular}


Table 1 continued

\begin{tabular}{|c|c|c|c|c|c|c|c|c|c|c|c|c|}
\hline \multirow{2}{*}{1995} & \multicolumn{3}{|c|}{ SOEs } & \multicolumn{3}{|c|}{ COEs } & \multicolumn{3}{|c|}{ PEs } & \multicolumn{3}{|c|}{ FEs } \\
\hline & coeff. & & t val. & coeff. & & t val. & coeff. & & t val. & coeff. & & t val. \\
\hline Male & 1.329 & $* * *$ & 6.39 & 0.801 & $* * *$ & 3.72 & 1.926 & $* * *$ & 4.12 & 1.124 & $* * *$ & 3.87 \\
\hline Han race & -0.946 & & -0.92 & -1.048 & & -1.01 & -1.068 & & -0.73 & -1.372 & & -1.18 \\
\hline Married & 0.837 & $* *$ & 2.13 & 0.891 & $* *$ & 2.18 & -0.008 & & -0.01 & -0.336 & & -0.68 \\
\hline Regions (Jiangsu) & & & & & & & & & & & & \\
\hline Anhui & 0.790 & $*$ & 1.90 & 0.701 & $*$ & 1.66 & 0.425 & & 0.33 & -0.862 & & -1.27 \\
\hline Henan & 0.975 & $* *$ & 2.45 & 0.108 & & 0.27 & 0.155 & & 0.12 & -2.524 & $* *$ & -2.31 \\
\hline Hubei & 0.168 & & 0.57 & -0.914 & $* * *$ & -2.97 & 0.079 & & 0.08 & -1.034 & $* *$ & -2.14 \\
\hline Guangdong & -0.105 & & -0.36 & -0.681 & $* *$ & -2.25 & 2.242 & $* * *$ & 2.78 & 0.608 & $*$ & 1.61 \\
\hline Sichuan & 0.280 & & 0.99 & -0.452 & & -1.53 & 0.498 & & 0.52 & -0.658 & & -1.49 \\
\hline Constants & 2.525 & $* *$ & 2.12 & 4.267 & $* * *$ & 3.51 & -1.161 & & -0.59 & 2.028 & & 1.44 \\
\hline Observation numbers & & & & 6131 & & & & & & & & \\
\hline Log likelihood & & & & -3822.831 & & & & & & & & \\
\hline Pseudo R2 & & & & 0.117 & & & & & & & & \\
\hline LR chi2 (65) & & & & 1013.6 & & & & & & & & \\
\hline Prob > chi2 & & & & 0.000 & & & & & & & & \\
\hline
\end{tabular}

Source: Calculated based on CHIP 1995. Notes. ${ }^{* *} p<0.01,{ }^{* *} p<0.05,{ }^{*} p<0.10$.

Table 2

Estimated Results of Probability Functions for the Firm Ownership (2007)

\begin{tabular}{|c|c|c|c|c|c|c|c|c|c|c|c|c|}
\hline \multirow{2}{*}{2007} & \multicolumn{3}{|c|}{ SOEs } & \multicolumn{3}{|c|}{ COEs } & \multicolumn{3}{|c|}{ PEs } & \multicolumn{3}{|c|}{ FEs } \\
\hline & coeff. & & t val. & coeff. & & t val. & coeff. & & t val. & coeff. & & t val. \\
\hline Schooling years & 0.087 & $* * *$ & 8.49 & 0.047 & $* *$ & 2.09 & -0.022 & * & -1.80 & 0.090 & $* * *$ & 3.20 \\
\hline \multicolumn{13}{|l|}{ Age (age 30-39) } \\
\hline Age 16-19 & -5.576 & $* * *$ & -7.72 & -17.340 & & -0.02 & -3.357 & $* * *$ & -9.03 & -17.016 & & -0.02 \\
\hline Age 20-29 & -0.771 & $* * *$ & -5.91 & -0.676 & $* *$ & -2.40 & -0.427 & $* * *$ & -2.98 & -0.612 & $* *$ & -1.85 \\
\hline Age 40-49 & 0.004 & & 0.04 & -0.096 & & -0.50 & -0.284 & $* *$ & -2.46 & -1.098 & $* * *$ & -3.74 \\
\hline Age 50-59 & -2.130 & $* * *$ & -20.43 & -2.479 & $* * *$ & -9.79 & -2.702 & $* * *$ & -20.34 & -3.087 & $* * *$ & -8.53 \\
\hline Male & 1.415 & $* * *$ & 18.56 & 1.408 & $* * *$ & 8.82 & 1.514 & $* * *$ & 17.20 & 1.513 & $* * *$ & 6.90 \\
\hline Han race & 0.340 & & 1.03 & 0.997 & & 0.96 & -0.002 & & -0.01 & 14.983 & & 0.01 \\
\hline Married & 1.180 & $* * *$ & 9.65 & 1.387 & $* * *$ & 4.64 & 1.459 & $* * *$ & 10.18 & 1.730 & $* * *$ & 4.39 \\
\hline \multicolumn{13}{|l|}{ Regions (Jiangsu) } \\
\hline Anhui & 0.346 & $* * *$ & 2.67 & -0.260 & & -0.97 & -0.092 & & -0.62 & -2.107 & $* * *$ & -3.89 \\
\hline Henan & -0.134 & & -1.08 & -0.657 & $* *$ & -2.47 & -0.774 & $* * *$ & -5.13 & -2.301 & $* * *$ & -4.68 \\
\hline Hubei & -0.258 & $*$ & -1.87 & -0.830 & $* * *$ & -2.57 & -0.475 & $* * *$ & -2.96 & -1.043 & $* * *$ & -2.75 \\
\hline Guangdong & -0.232 & $*$ & -1.92 & -0.240 & & -1.03 & -0.097 & & -0.74 & -0.678 & $* *$ & -2.53 \\
\hline Sichuan & -0.037 & & -0.30 & -0.533 & $* *$ & -1.99 & -0.297 & $* *$ & -2.08 & -1.121 & $* * *$ & -3.26 \\
\hline Constants & -2.064 & $* * *$ & -5.40 & -4.352 & $* * *$ & -3.87 & -1.038 & $* *$ & -2.42 & -19.006 & & -0.01 \\
\hline Observation numbers & & & & 5940 & & & & & & & & \\
\hline Log likelihood & & & & -6407.34 & & & & & & & & \\
\hline Pseudo R2 & & & & 0.170 & & & & & & & & \\
\hline LR chi2 (65) & & & & 2617.08 & & & & & & & & \\
\hline Prob > chi2 & & & & 0.000 & & & & & & & & \\
\hline
\end{tabular}

Source: Calculated based on CHIP 2007. Notes. ${ }^{* *} p<0.01,{ }^{* *} p<0.05,{ }^{*} p<0.10$. 


\section{Are There Wage Structure Differences Between Sectors?}

The estimated results of the selectivity-bias corrected wage functions based on variable mean values (OLS models) are reported in Table 3 (1995), Table 4 (2007). The coefficients of corrected items are statistically significant for PEs in 1995, and COEs, FEs in 2007. These results indicated that the utilization of the selectivity-bias corrected wage functions to address the sample selection bias problem is necessary. Following are the main conclusions:

Table 3

Estimated Results of Wage Functions by Sectors (1995)

\begin{tabular}{|c|c|c|c|c|c|c|c|c|c|c|c|c|c|c|}
\hline \multirow{2}{*}{1995} & \multicolumn{3}{|c|}{ Total } & \multicolumn{3}{|c|}{ SOES } & \multicolumn{3}{|c|}{ COEs } & \multicolumn{2}{|l|}{ PEs } & \multicolumn{3}{|c|}{ FEs } \\
\hline & coeff. & & t val. & coeff. & & t val. & coeff. & & $\mathrm{t}$ val. & coeff. & t val. & coeff. & & t val. \\
\hline Schooling years & 0.036 & $* * *$ & * 5.49 & 0.021 & $* * *$ & 3.66 & 0.058 & $* * *$ & 2.74 & 0.145 & 0.84 & 0.049 & $*$ & 1.87 \\
\hline Tenure years & 0.008 & $* *$ & 2.25 & 0.009 & $* *$ & 2.41 & 0.005 & & 0.58 & -0.390 & -1.68 & 0.048 & & 1.32 \\
\hline Tenure years square & $-1.143 \mathrm{E}-04$ & & -1.19 & $-1.607 \mathrm{E}-04$ & & -1.60 & $-1.466 \mathrm{E}-04$ & & -0.54 & 0.022 & 1.54 & -0.001 & & -1.06 \\
\hline Age & 0.061 & $* * *$ & * 7.81 & 0.064 & $* * *$ & 8.76 & 0.110 & $* * *$ & ${ }^{k} 6.06$ & 0.131 & 0.33 & 0.001 & & 0.01 \\
\hline Age square & -0.001 & $* * *$ & $*-5.83$ & -0.001 & $* * *$ & -6.61 & -0.001 & $* * *$ & -5.26 & -0.001 & -0.16 & $5.480 \mathrm{E}-05$ & & 0.07 \\
\hline Male & 0.084 & $* * *$ & * 3.92 & 0.065 & $* * *$ & 3.08 & 0.157 & $* * *$ & k 2.62 & -0.593 & -0.59 & 0.058 & & 0.49 \\
\hline Han race & 0.136 & $* * *$ & * 2.64 & 0.162 & $* * *$ & 2.99 & -0.004 & & -0.03 & 2.820 & 1.10 & -0.325 & & -0.86 \\
\hline Occupation (others) & & & & & & & & & & & & & & \\
\hline Blue-collar worker & -0.174 & $* * *$ & $*-10.7$ & -0.188 & $* * *$ & -10.67 & -0.074 & $* *$ & -1.88 & 0.020 & 0.02 & -0.088 & & -0.7 \\
\hline Employment (others) & & & & & & & & & & & & & & \\
\hline regular & 0.237 & $* * *$ & * 6.03 & 0.233 & $* * *$ & 3.69 & 0.293 & $* * *$ & k 3.99 & -0.764 & -0.76 & -0.074 & & -0.52 \\
\hline Industry (others) & & & & & & & & & & & & & & \\
\hline Manufacturing & 0.099 & $* * *$ & * 2.94 & 0.094 & $* * *$ & 2.67 & 0.117 & & 1.33 & (omitted) & & 0.224 & & 0.52 \\
\hline Province (Jiangsu) & & & & & & & & & & & & & & \\
\hline Anhui & -0.317 & $* * *$ & * - -11.56 & -0.311 & $* * *$ & -10.66 & -0.307 & $* * *$ & -5.56 & -0.225 & -0.09 & -0.351 & & -1.08 \\
\hline Henan & -0.445 & $* * *$ & * -11.57 & -0.479 & $* * *$ & -13.27 & -0.356 & $* * *$ & k -3.48 & (omitted) & & -1.595 & $* * *$ & -2.73 \\
\hline Hubei & -0.187 & $* * *$ & * -4.54 & -0.230 & $* * *$ & -6.61 & -0.144 & & -1.24 & -1.273 & -0.65 & -0.360 & & -1.52 \\
\hline Guangdong & 0.400 & $* * *$ & * 10.49 & 0.350 & $* * *$ & 12.56 & 0.616 & $* * *$ & k 6.89 & -0.574 & -0.29 & 0.643 & $* * *$ & 3.72 \\
\hline Sichuan & -0.201 & $* * *$ & $*-5.97$ & -0.228 & $* * *$ & -7.42 & -0.180 & $* *$ & -2.02 & 1.535 & 0.80 & -0.486 & $* *$ & -2.34 \\
\hline $\begin{array}{l}\text { Corrected item } 2 \\
\text { (SOEs) }\end{array}$ & -0.610 & & -0.94 & -0.350 & & -0.93 & & & & & & & & \\
\hline $\begin{array}{l}\text { Corrected item } 3 \\
\text { (COEs) }\end{array}$ & -0.528 & & -0.80 & & & & -1.035 & & -1.04 & & & & & \\
\hline $\begin{array}{l}\text { Corrected item } 4 \\
\text { (PEs) }\end{array}$ & -5.837 & $* *$ & -2.48 & & & & & & & -30.419 & -0.76 & & & \\
\hline $\begin{array}{l}\text { Corrected item } 5 \\
\text { (FEs) }\end{array}$ & 0.741 & & 0.72 & & & & & & & & & 5.899 & $* *$ & 2.34 \\
\hline Constants & 3.483 & $*$ & 1.79 & -0.898 & $* * *$ & -3.06 & -1.721 & $* * *$ & k -2.95 & 18.851 & 0.65 & -3.896 & $* * *$ & -2.69 \\
\hline $\begin{array}{l}\text { Observation } \\
\text { numbers }\end{array}$ & 5922 & & & 4674 & & & 2619 & & & 24 & & 104 & & \\
\hline $\mathrm{R} 2$ & 0.5422 & & & 0.3341 & & & 0.3435 & & & 0.0802 & & 0.3197 & & \\
\hline
\end{tabular}

Source: Calculated based on CHIP 1995. Notes. ${ }^{* * *} p<0.01,{ }^{* *} p<0.05,{ }^{*} p<0.10$. 
Table 4

Estimated Results of Wage Functions by Sectors (2007)

\begin{tabular}{|c|c|c|c|c|c|c|c|c|c|c|c|c|c|c|c|}
\hline \multirow{2}{*}{2007} & \multicolumn{3}{|c|}{ Total } & \multicolumn{3}{|c|}{ SOEs } & \multicolumn{3}{|c|}{ COEs } & \multicolumn{3}{|c|}{ PEs } & \multicolumn{3}{|c|}{ FEs } \\
\hline & coeff. & & t val. & coeff. & & t val. & coeff. & & t val. & coeff. & & t val. & coeff. & & t val. \\
\hline Schooling years & 0.030 & $* * *$ & 5.09 & 0.035 & $* * *$ & 7.22 & 0.022 & $*$ & 1.86 & 0.033 & $* * *$ & 5.32 & 0.024 & $*$ & 1.71 \\
\hline Tenure years & 0.016 & $* * *$ & $=15.29$ & 0.017 & $* * *$ & 12.83 & -0.003 & & -0.20 & 0.042 & $* * *$ & 5.98 & 0.051 & $*$ & 1.92 \\
\hline Tenure years square & $-9.190 \mathrm{E}-06$ & $* * *$ & -17.06 & $-9.470 \mathrm{E}-06$ & $* * *$ & -14.36 & 8.060E-05 & & 0.17 & -0.001 & $* * *$ & -4.75 & -0.001 & & -1.34 \\
\hline Age & 0.023 & $*$ & 1.88 & 0.023 & & 1.52 & -0.039 & & -0.87 & 0.039 & $* *$ & 2.19 & 0.041 & & 0.95 \\
\hline Age square & $-3.015 E-04$ & $*$ & -1.90 & $-3.207 E-04$ & $*$ & -1.64 & 4.354E-04 & & 0.74 & -0.001 & $* *$ & -2.22 & 0.000 & & -0.86 \\
\hline Male & -0.009 & & -0.31 & 0.007 & & 0.19 & -0.033 & & -0.35 & 0.028 & & 0.61 & 0.007 & & 0.06 \\
\hline Han race & 0.224 & $* *$ & 2.14 & 0.201 & $*$ & 1.61 & 0.047 & & 0.10 & 0.149 & & 0.98 & -0.140 & & -0.30 \\
\hline \multicolumn{16}{|l|}{ Occupation (others) } \\
\hline Blue-collar worker & -0.209 & $* *$ & -2.34 & -0.370 & $* * *$ & -3.22 & -0.211 & & -0.84 & 0.205 & & 1.15 & 0.405 & & 0.60 \\
\hline \multicolumn{16}{|l|}{ Employment (others) } \\
\hline Regular & 0.371 & $* * *$ & $=15.40$ & 0.420 & $* * *$ & 9.61 & 0.339 & $* * *$ & 3.02 & 0.308 & $* * *$ & 8.28 & 0.334 & $* *$ & 2.27 \\
\hline \multicolumn{16}{|l|}{ Industry (others) } \\
\hline Manufacturing & 0.001 & & 0.01 & 0.151 & & 1.32 & 0.017 & & 0.06 & -0.396 & $* *$ & -2.16 & -0.701 & & -1.04 \\
\hline \multicolumn{16}{|l|}{ Province (Jiangsu) } \\
\hline Anhui & -0.121 & $* *$ & -2.03 & -0.139 & $* * *$ & -2.83 & -0.073 & & -0.45 & -0.447 & $* * *$ & -6.86 & 0.485 & & 1.26 \\
\hline Henan & -0.207 & $* * *$ & -3.91 & -0.351 & $* * *$ & -7.42 & -0.073 & & -0.51 & -0.345 & $* * *$ & -4.73 & 0.037 & & 0.11 \\
\hline Hubei & -0.113 & $* *$ & -1.94 & -0.191 & $* * *$ & -3.64 & -0.093 & & -0.51 & -0.080 & & -1.12 & -0.106 & & -0.46 \\
\hline Guangdong & 0.514 & $* * *$ & 13.54 & 0.489 & $* * *$ & 10.45 & 0.378 & $* * *$ & 3.03 & 0.376 & $* * *$ & 6.84 & 0.573 & $* * *$ & $=3.10$ \\
\hline Sichuan & -0.206 & $* * *$ & -3.96 & -0.225 & $* * *$ & -4.73 & -0.030 & & -0.20 & -0.356 & $* * *$ & -5.67 & -0.147 & & -0.59 \\
\hline $\begin{array}{l}\text { Corrected item } 2 \\
\text { (SOEs) }\end{array}$ & -0.393 & & -0.93 & 0.112 & & 0.35 & & & & & & & & & \\
\hline $\begin{array}{l}\text { Corrected item } 3 \\
\text { (COEs) }\end{array}$ & 8.942 & $* *$ & 2.04 & & & & -2.688 & & -0.34 & & & & & & \\
\hline $\begin{array}{l}\text { Corrected item } 4 \\
\text { (PEs) }\end{array}$ & -0.280 & & -0.53 & & & & & & & 0.554 & & 0.97 & & & \\
\hline $\begin{array}{l}\text { Corrected item } 5 \\
\text { (FEs) }\end{array}$ & -7.858 & $* * *$ & -4.95 & & & & & & & & & & -6.028 & & -0.89 \\
\hline Constants & 0.538 & & 0.18 & 0.814 & & 1.56 & 4.545 & & 0.66 & 0.362 & & 0.57 & 5.715 & & 1.00 \\
\hline $\begin{array}{l}\text { Observation } \\
\text { numbers }\end{array}$ & 4707 & & & 2639 & & & 267 & & & 1573 & & & 142 & & \\
\hline $\mathrm{R} 2$ & 0.2809 & & & 0.2891 & & & 0.1539 & & & 0.2647 & & & 0.2932 & & \\
\hline
\end{tabular}

Source: Calculated based on CHIP 2007. Notes. ${ }^{* *} p<0.01,{ }^{* *} p<0.05,{ }^{*} p<0.10$.

First, rates of return on education in SOEs rose from 2.1\% in 1995 to 3.5\% in 2007. Otherwise, in COEs, it decreased from 5.8\% in 1995 to 2.2\% in 2007, and in PEs, it decreased from $4.9 \%$ in 1995 to $2.4 \%$ in 2007. In FEs, coefficient is statistically insignificant in 1995, while it became statistically significant in 2007. Effects of education on wage levels in SOEs and FEs became greater, while education effects decreased in SOEs and PEs along with economic marketization progress. Results indicated that the changes of education effects are different by firm ownership types.

Second, coefficients of tenure in SOEs rose from 0.009 in 1995 to 0.017 in 2007. In PEs and FEs, coefficients of tenure were statistically insignificant in 1995, but they became statistically significant in 2007. In COEs, coefficients of tenure were statistically insignificant either in 1995 or 2007. Overall, firm-specific human capital became more important in the wage determination mechanism along with market-oriented reforms. 
Third, in 1995, coefficients of age are statistically significant in SOEs and COEs, but in 2007, age showed no significant effect on wages in these two sectors. Otherwise, in 1995 coefficients of age were statistically insignificant in PEs and FEs, but in 2007, age showed significant effect on wages in these two sectors.

Wage reforms in SOEs enforced by Chinese government might explain these results, for example, the seniority wage system was reformed after the 1980s and the previously described performance payment systems were established in SOEs (Ma, 2006). Therefore, age became less of a factor in SOEs wages, while human capital (education and tenure) were rewarded more in 2007. Otherwise, seniority wage system maybe has a spillover effect to affect the wage determinants systems in the private sectors (e.g., PEs and FEs). As a result, the wage structures show a convergence tendency among these public and private sectors.

Fourth, the occupation wage differentials are significant in SOEs, but they are not severe in PEs and FEs.

Fifth, industrial wage differentials are different by the ownership types. For example, coefficients of manufacture industry dummy are negatively significant in 1995 and 2007 (they changed from -0.188 in 1995 to -0.370 in 2007), but in PEs and FEs, coefficients of manufacture industry dummy are statistically insignificant in both 1995 and 2007.

Sixth, employment status (regular worker, irregular worker) affect wage levels. In 2007, compared with irregular worker group, wage levels are 30.8\%-40.3\% higher in regular worker groups.

Seventh, there existed regional wage disparity both in 1995 and 2007.

\section{Are There Wage Structure Differences Between Sectors by Wage Distributions?}

Figure 2 provides the estimated results from the QR model. The wage structures by wage percentiles become apparent as follows:

First, from 1995 to 2007, education return rates increased in SOE across the entire percentiles, while for COEs and FEs, education return rates decreased in the whole percentiles.

In addition, education return rates are different by the wage distributions. For example, in 2007, in SOEs, education return rates are higher for low-wage and middle-wage groups, and the effect is the highest at the 40th percentile.

These results indicate that market mechanisms attained greater influence on wages among low-wage and middle-wage groups along with the progress of economy reforms. Otherwise, in COEs and FEs, education return rates are higher for high-wage groups, and the effect is the highest at the 70th percentile in COEs and the 70th percentile in FEs.

Second, compared with 1995, coefficients of tenure decreased across the entire wage distribution in SOEs. In COEs, coefficients of tenure decreased at 6th-50th and increased at 60th-90th percentiles. In FEs, coefficients of tenure decreased at 6th-20th and increased at 30th-90th percentiles.

In addition, effects of tenure are different by wage distributions. For example, in 2007, coefficients of tenure are higher in middle-wage groups (40th-80th) in SOEs, COEs, and FEs. Firm-specific human capital became more important on wage determinants for middle-wage groups along with the economic transition.

Third, in middle-wage and high-wage groups, the influence of age on wage declined from 1995 to 2007 in SOEs, COEs, and FEs. In low-wage groups, age effects decreased in SOEs and COEs, while age effects rose in low-wage group (at 5th-20th wage percentiles) of FEs. Reform of China's seniority wage system had a greater relative effect across the entire wage distribution in SOEs, and the wage system reform showed some spillover effects to influence the wage distributions in the private sectors (COEs, FEs, and PEs). 
In addition, age effects are different by wage distributions. For example, in 2007, coefficients of year are higher in low-wage groups (5th-30th) in SOEs, FEs, and PEs.

Estimated results of schooling years

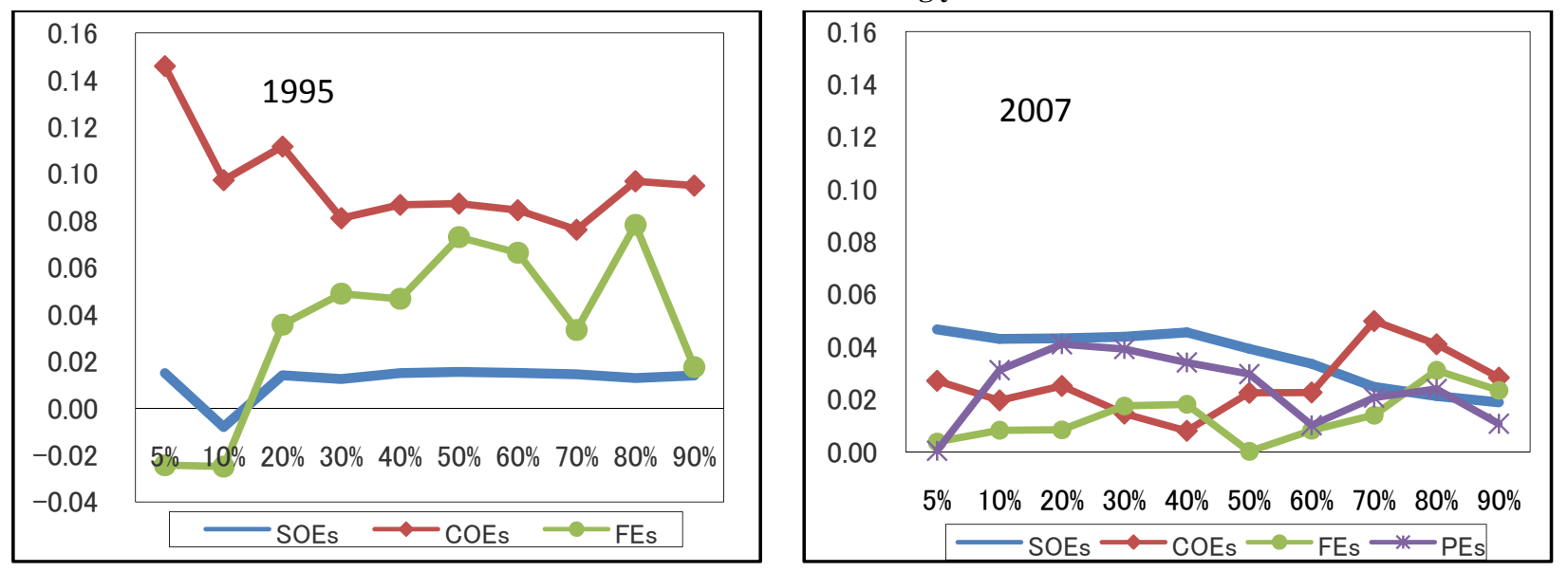

Estimated results of tenure years

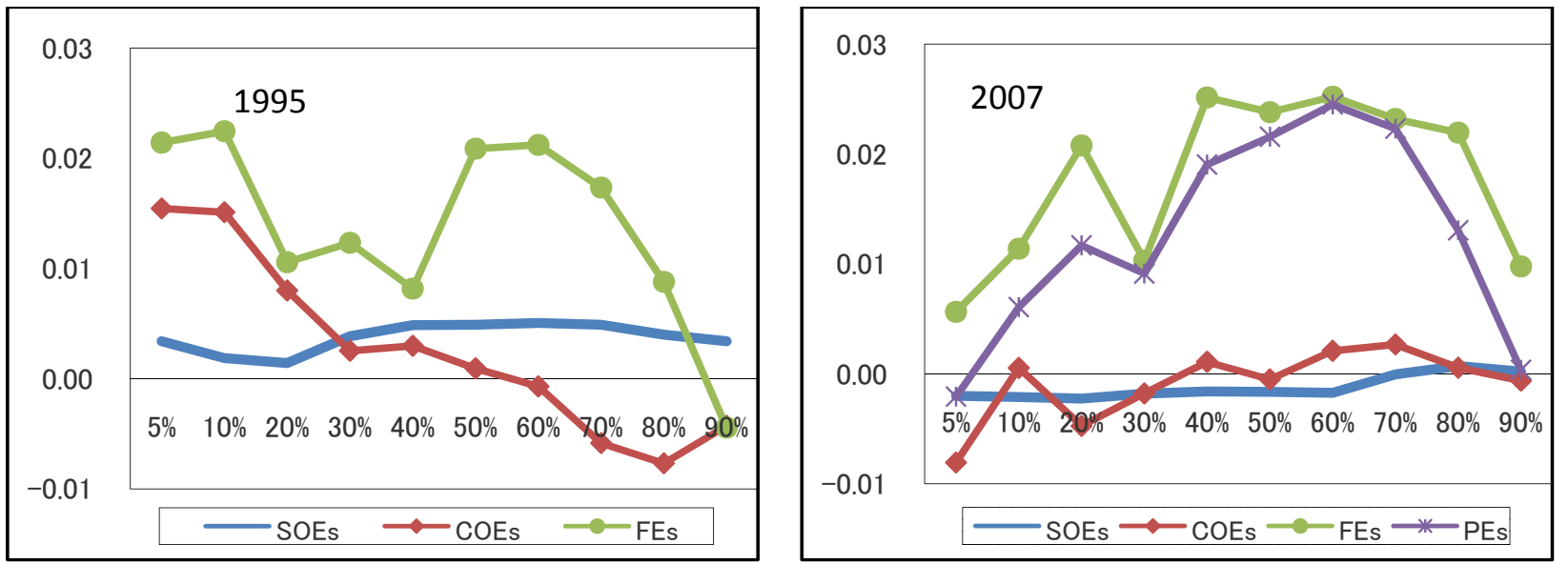

Estimated results of age
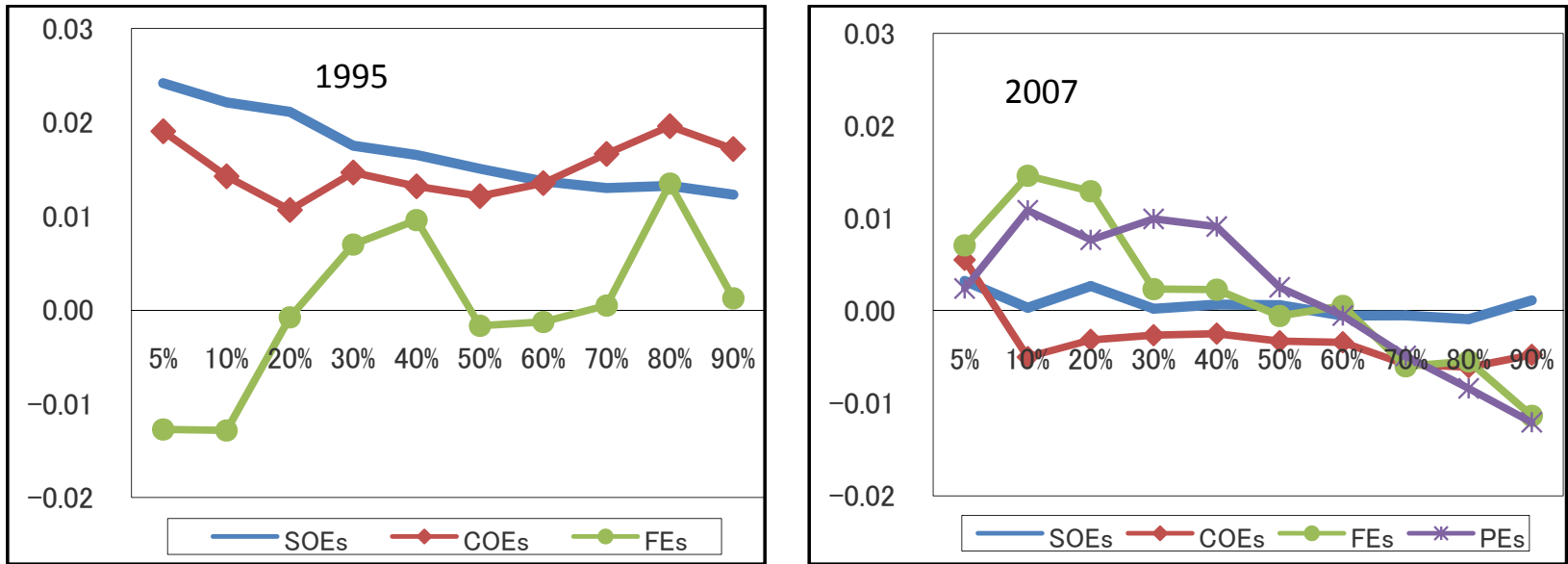

Figure 2. Estimated results of wage functions by sectors and wage percentiles (QR models). Source: Calculated based on CHIP 1995 and CHIP 2007. Notes. (1) male, race, the married, occupation, industry, and province are estimated, but these have not been shown in Figure 2; (2) Because the samples of PEs are so scarely, the analysis has not been taken for PEs in 1995. 


\section{Conclusions}

Under economic transition, China is experiencing major changes in wage policies and wage systems. This paper has empirically assessed how China's wage policy reforms affected wage determination mechanisms by ownership types (SOEs, COEs, FEs, and PEs). Using the CHIP data and the sample selection bias corrected wage function model, this paper estimated changes in wage structure in 1995 and 2007. The major conclusions are as follows.

First, effects of education on wage levels in SOEs and FEs became greater, while education effects decreased in SOEs and PEs under economic transition periods; firm-specific human capital (tenures as index) became more important in the wage determination mechanism along with market-oriented reforms in SOEs, PEs, and FEs; age effect decreased in SOEs and COEs, but it became greater in PEs and FEs.

Second, there exist wage structure differences between sectors by wage distributions. For example, in 2007, in SOEs, education return rates are higher for low-wage and middle-wage groups, and the effect is the highest at the 40th percentile. While in COEs and FEs, education return rates are higher for high-wage groups, and the effect is the highest at the 70th percentile in COEs and at the 70th percentile in FEs. Tenure effects are greater in middle-wage groups (40th-80th) in SOEs, COEs, and FEs, and age effects are greater in low-wage groups (5th-30th) in SOEs, FEs, and PEs.

Finally, some research limitations should be pointed out. Although using the employee information from CHIP (1995 and 2007), the wage structures are estimated by ownership types. It is thought that other labor demand factors, such as firm productivity, firm HRM (human resource management) systems, and unobservable variables of firms and individuals, should affect individual wage levels. Using employer-employee matched data and panel data to estimate wage structure are the future research issues. In addition, how do the changes of wage structures affect wage differentials between sectors? It is valuable to take another analysis to answer the questions. All of these research issues will be in the future.

\section{References}

Becker, G. S. (1964). Human capital: A theoretical and empirical analysis, with special reference to education (1st ed.). New York: Columbia University Press.

Bowles, P., \& White, G. (1998). Labor systems in transitional economies: An analysis of China's township and village enterprises (Labor Markets in Transition: International Dimensions, International Review of Comparative Public Policy, No. 10). Stamford, Conn.: JAI Press.

Chen, G., Demurger, S., \& Fournier, M. (2005). Wage differentials and ownership structure of China's enterprises. World Economic Paper, 6, 11-31. (In Chinese)

Demurger, S., Fournier, M., Li, S., \& Wei, Z. (2007). Economic liberation with rising segmentation in China's urban labor market. Asian Economic Papers, 5(3), 58-103.

Demurger, S., Li, S., \& Yang, J. (2012). Earning differentials between the public and private sectors in China: Exploring changes for urban local residents in the 2002s. China Economic Review, 23, 138-153.

Dong, X., \& Bowles, P. (2002). Segmentation and discrimination in China's emerging industrial labor market. China Economic Review, 13, 170-196.

Heckman, J. J. (1979). Sample selection bias as a specification error. Econometrica, 47(1), 153-161.

Koenker, R. W., \& Bassett, G. J. (1978). Regression quantile. Econometrica, 46(1), 33-50.

Li, S., \& Ma, X. (2015). Impact of minimum wage on gender wage gaps in Urban China. IZA Journal of Labor \& Development, November, 2015, 4:20 doi: 10.1186/s40175-015-0044-4.

Lin, Y., Cai, F., \& Li, Z. (1996). Miracle development strategy and economic reform in China. Shanghai: Shanghai People. Maddala, G. S. (1983). Limited-dependent and qualitative variables in econometrics. New York: Cambridge University Press. Ma, X. (2006). Overview and feature of wage systems in modern Chinese enterprises. Labor Studies, 59(10), 19-27. (In Japanese) 
Ma, X. (2007). An empirical analysis of factor decomposition of differences between Japan and China of male-female wage differentials. The Japanese Journal of Labor Studies, 49(560), 96-107. (In Japanese)

Ma, X. (2009). The enterprise ownership reforms and the change of wage structure in China: Comparison of gender wage profiles differentials by ownership. Journal of Chinese Economic Studies, 6(1), 48-64. (In Japanese)

Ma, X. (2014). Wage policy: Economy transition and wage differentials of sectors. In K. Nakagane (Ed.), How did Chinese economy change? Evaluation of economic systems and policies in post-reform period. Tokyo: Kokusai Shoin Co., Ltd. (In Japanese)

Ma, X. (2015). Economic transition and wage differentials between public and private sectors in China. China-USA Business Review, 14(10), 477-494.

Marugawa, T. (2002). Series contemporary Chinese economy 3: Crustal change in the labor market. Nagoya: Nagoya University Publishing.

Meng, X., \& Kidd, M. P. (1997). Labor market reform and the changing structure of wage determination in China's state sector during the 1980s. Journal of Comparative Economics, 25, 403-421.

Mincer, J. (1974). Schooling, experience and earning. New York: Columbia University Press.

Nakagane, K. (1999). Economic development in China. Tokyo: Yuhikaku Publishing. (In Japanese)

Ono, A. (1989). Labor market and employment practices in Japan. Tokyo: Toyo Keizai Sinhosya Press. (In Japanese)

Piore, M. J. (1970). Job and training. In S. H. Beer and R. Barringer (Eds.), The state and the poor (pp. 53-83). Cambridge, MA: Winthrop.

Xing, C. (2006). Wage decision and returns to education by ownerships in China based on quantile regression. World Economic Papers, 1, 1-25.

Yamamoto, T. (2000). Labor economics in modern China: From rational low wage system to modern labor market. Seitama: Sotosya Press, Seitama, Japan. (In Japanese)

Ye, L., Li, S., \& Luo, C. (2011). Industrial monopoly, ownership and enterprises wage inequality: An empirical research based on the first national economic census of enterprises data. Management World, 4, 26-36. (In Chinese)

Yin, Z., \& Gan, L. (2009). Wage differentials between public and nonpublic sector in China. Economic Research, 4, 129-140. (In Chinese)

Zhang, J., \& Xue, X. (2008). State and non-state sector wage differentials and human capital contribution. Economic Research, 4, 15-25. (In Chinese)

Zhang, Y. (2012). The change of income differentials between public and nonpublic sector in China. Economic Research, 4, 77-88. (In Chinese) 